\title{
Methanosphaerula palustris gen. nov., sp. nov., a hydrogenotrophic methanogen isolated from a minerotrophic fen peatland
}

Correspondence

Stephen H. Zinder

shz1@cornell.edu

\author{
Hinsby Cadillo-Quiroz, ${ }^{1}$ Joseph B. Yavitt ${ }^{2}$ and Stephen H. Zinder $^{1}$ \\ ${ }^{1}$ Department of Microbiology, Cornell University, Ithaca, NY 14853, USA \\ ${ }^{2}$ Department of Natural Resources, Cornell University, Ithaca, NY 14853, USA
}

\begin{abstract}
Peatlands are important sources of $\mathrm{CH}_{4}$ emissions to the atmosphere and molecular surveys have identified a diverse, but mainly uncultured, euryarchaeal community in them. Characterization of a strain, E1-9c ${ }^{\top}$, associated with uncultured group E1, from a minerotrophic fen is reported. Cells were regular cocci, usually found in pairs, that stained Gram-positive and were resistant to lysis by $0.1 \%$ SDS. Multiple flagella were observed, but motility was not observed in wet mounts. Optimal growth was obtained at moderate temperatures $\left(28-30{ }^{\circ} \mathrm{C}\right)$ and slightly acidic $\mathrm{pH}$ (5.5). Total $\mathrm{Na}^{+}$and $\mathrm{NaCl}$ were only tolerated at concentrations less than $100 \mathrm{mM}$ and $0.5 \%$, respectively, and $\mathrm{Na}_{2} \mathrm{~S}$ concentrations above $0.1 \mathrm{mM}$ were inhibitory. $\mathrm{H}_{2} / \mathrm{CO}_{2}$ and formate were the only methanogenic substrates used by $\mathrm{E} 1-9 \mathrm{c}^{\top}$; formate concentrations above $50 \mathrm{mM}$ were inhibitory for growth. Vitamins, coenzyme $\mathrm{M}$ and acetate $(4 \mathrm{mM})$ were required for growth and the doubling time was about $19 \mathrm{~h}$. Phylogenetic analysis of the 16S rRNA gene and inferred McrA amino acid sequences showed that $\mathrm{E} 1-9 \mathrm{c}^{\top}$ represented an independent lineage within the order

Methanomicrobiales. Physiological and phylogenetic comparisons with different members of the order supported classification of $\mathrm{E} 1-9 \mathrm{c}^{\top}$ in a new genus in the Methanomicrobiales. The name Methanosphaerula palustris gen. nov., sp. nov. is proposed; strain E1-9c ${ }^{\top}$ (=ATCC BAA-1565 ${ }^{\top}$ $=$ DSM $19958^{\top}$ ) is the type strain of Methanosphaerula palustris.
\end{abstract}

Peat-forming wetlands or peatlands (Gore, 1983) store nearly $30 \%$ of all terrestrial carbon (Gorham, 1991) and are estimated to contribute around $20 \%(115 \mathrm{Tg})$ of total annual $\mathrm{CH}_{4}$ emissions to the atmosphere (Cicerone \& Oremland, 1988). Hence, the methanogenic archaea inhabiting these ecosystems are of importance, particularly since the $\mathrm{CH}_{4}$ concentration in the atmosphere has more than doubled in the past 200 years (Cicerone \& Oremland, 1988). Surveys of $16 \mathrm{~S}$ rRNA gene sequences from acidic and neutral $\mathrm{pH}$ peatlands have shown a broad diversity of euryarchaeal sequences (Cadillo-Quiroz et al., 2006, 2008; Galand et al., 2003; Kotsyurbenko et al., 2004). The majority of sequences are not closely related to cultured strains, but instead form independent clusters, suggesting the existence of novel euryarchaeal groups. Two of these clusters, named groups E1 and E2 in the

Abbreviations: TEM, transmission electron microscopy; T-RFLP, terminal restriction fragment length polymorphism.

The GenBank/EMBL/DDBJ accession numbers for the 16S rRNA and $m c r A$ gene sequences of strain E1-9c ${ }^{\top}$ are EU156000 and EU296536, respectively.

Plots showing the effects of sodium ion concentration on growth of strain $E 1-9 c^{\top}$ and formate utilization by strain $E 1-9 c^{\top}$ are available as supplementary material with the online version of this paper.
Methanomicrobiales (Cadillo-Quiroz et al., 2006), have been shown to be highly abundant in clone libraries and by terminal restriction fragment length polymorphism (TRFLP) analysis of samples from acidic bogs and nearneutral pH fen peatlands (Basiliko et al., 2003; CadilloQuiroz et al., 2006, 2008).

Several phylogenetic analyses have shown that E1- and E2related sequences form independent branches within the Methanomicrobiales (Basiliko et al., 2003; Cadillo-Quiroz et al., 2006, 2008; Galand et al., 2003; Hales et al., 1996). The order Methanomicrobiales is diverse and its members exhibit great morphological and physiological variability (Dubach \& Bachofen, 1985). This order comprises the families Methanomicrobiaceae, Methanocorpusculaceae and Methanospirillaceae (Boone et al., 2001; Garcia et al., 2000). It also includes three genera that are not placed within any family: the genus Methanocalculus, which is listed as a genus incertae sedis (Boone et al., 2001), with four reported species (Lai et al., 2002, 2004; Mori et al., 2000; Ollivier et al., 1998), the proposed genus 'Candidatus Methanoregula', with one species, 'Candidatus Methanoregula boonei', isolated from an acidic bog (Bräuer et al., 2006a, b), and the recently described genus Methanolinea, with one species, Methanolinea tarda, isolated from sewage sludge (Imachi et al., 2008). 
'Candidatus Methanoregula boonei' is a member of the E2 group and was isolated using low-ionic-strength media and reducing agents other than $\mathrm{Na}_{2} \mathrm{~S}$ to avoid inhibition of growth (Bräuer et al., 2006b). Recently, the isolation of a novel methanogen, designated strain $\mathrm{E} 1-9 \mathrm{c}^{\mathrm{T}}$, using the same culture medium coupled to T-RFLP analysis as a screening tool (Cadillo-Quiroz et al., 2008) has been reported. Strain E1-9c $\mathrm{c}^{\mathrm{T}}$ was isolated from a minerotrophic fen in upstate New York $\left(42^{\circ} 21^{\prime} \mathrm{N} 76^{\circ} 28^{\prime} \mathrm{W}\right)$ where sequences belonging to the $\mathrm{E} 1$ group were diverse and abundant (Cadillo-Quiroz et al., 2008). In our previous paper, conditions that enriched and allowed for isolation of a member of the E1 group, using T-RFLP analysis as a selection and tracking tool, were reported. Culture purity was evaluated by culture techniques, phase-contrast microscopy, fluorescent in situ hybridization, T-RFLP analysis and clone library analysis and strain $\mathrm{E} 1-9 \mathrm{c}^{\mathrm{T}}$ was proposed as the first member of a novel genus within the Methanomicrobiales. In this report, a more detailed evaluation of the morphological, physiological and phylogenetic characteristics of strain E1-9c $\mathrm{C}^{\mathrm{T}}$ is presented and the novel species Methanosphaerula palustris gen. nov., sp. nov., represented by strain E1-9c $\mathrm{c}^{\mathrm{T}}$, is described.

PM2 medium, a modified version of PM1 medium (Bräuer et al., 2006b), was used. It contains the following components $\left(\mathrm{mg} \mathrm{l}^{-1}\right): 1.5 \mathrm{KCl}, 13.6 \quad \mathrm{KH}_{2} \mathrm{PO}_{4}, 26.8$ $\mathrm{NH}_{4} \mathrm{Cl}, 0.024 \mathrm{CoCl}_{2} .6 \mathrm{H}_{2} \mathrm{O}, 0.075 \mathrm{ZnCl}_{2}, 0.019 \mathrm{H}_{3} \mathrm{BO}_{3}$, $0.024 \quad \mathrm{NiCl}_{2} \cdot 6 \mathrm{H}_{2} \mathrm{O}, \quad 0.024 \quad \mathrm{Na}_{2} \mathrm{MoO}_{4} \cdot 2 \mathrm{H}_{2} \mathrm{O}, \quad 1.3$ $\mathrm{FeCl}_{2} \cdot 4 \mathrm{H}_{2} \mathrm{O}, \quad 0.026 \quad \mathrm{MnSO}_{4} \cdot 4 \mathrm{H}_{2} \mathrm{O}, \quad 1.6 \mathrm{MgSO}_{4}, \quad 2.4$ $\mathrm{CaCl}_{2} \cdot 2 \mathrm{H}_{2} \mathrm{O}, 0.009 \mathrm{CuSO}_{4} \cdot 5 \mathrm{H}_{2} \mathrm{O}, 3.5 \mathrm{AlK}\left(\mathrm{SO}_{4}\right)_{2} \cdot 12 \mathrm{H}_{2} \mathrm{O}$ and 3.7 disodium EDTA. Medium was prepared under a $70 \% \mathrm{~N}_{2} / 30 \% \mathrm{CO}_{2}$ atmosphere as described previously (Bräuer et al., 2006b) using the modified anaerobic technique of Hungate (Sowers \& Noll, 1995). Several hours before inoculation, sterile anaerobic additions were made to the basal medium with the following final concentrations: $1.0 \mathrm{mM}$ titanium (III) nitrilotriacetate $[7.2 \mathrm{ml} 1 \mathrm{M}$ Tris/ $\mathrm{HCl}$ adjusted to $\mathrm{pH} 8,4.8 \mathrm{ml} 0.5 \mathrm{M}$ sodium nitrilotriacetate and $0.55 \mathrm{ml} 15 \%$ titanium (III) chloride (Fluka)]; $10 \mathrm{mM}$ MES (filter-sterilized $1 \mathrm{M}$ stock solution adjusted to $\mathrm{pH} 7.5$ ); $0.5 \mathrm{mM}$ coenzyme M (2mercapthoethanesulfonic acid); $0.4 \mathrm{mM}$ sodium acetate; $1 \%(\mathrm{v} / \mathrm{v})$ vitamin solution (Balch et al., 1979); and $0.04 \mathrm{mM} \mathrm{Na}_{2} \mathrm{~S} .9 \mathrm{H}_{2} \mathrm{O}$ (filter-sterilized $20 \mathrm{mM}$ stock solution). The final liquid volumes in the tubes were $\sim 5 \mathrm{ml}$ and $\mathrm{H}_{2} / \mathrm{CO}_{2}(80 \% / 20 \% ; 70.7 \mathrm{kPa})$ was added to the headspace unless otherwise specified. Cultures were incubated on a gyratory shaker at $30{ }^{\circ} \mathrm{C}$ and 200 r.p.m. and all evaluations were done for over 29 days.

Cell morphology and motility were examined by phasecontrast microscopy with a Nikon Eclipse E600 microscope. Gram staining and determination of susceptibility to lysis in the presence of SDS were done as described previously (Boone \& Whitman, 1988). SDS tests were performed at final concentrations of $0.1-5.0 \%(\mathrm{w} / \mathrm{v})$ and lysis was determined by microscopic observations. Negative-staining, ultrathin-sectioning transmission elec- tron microscopy (TEM) was performed as described elsewhere (Firtel et al., 1995) using 2\% uranyl acetate (pH 6.5) and a Phillips Technai 12 Biotwin electron microscope equipped with a Gatan Multiscan model 791 camera and Digital Micrograph software. Photos were taken at $100 \mathrm{kV}$. Flagella observations were done with low uranyl acetate staining $(0.2 \%)$ and images were enhanced digitally using the Photoshop software by a differential adjustment of the brightness and contrast of cell body and flagella versus background surface.

When determining the effect of total sodium on growth of strain E1-9 $\mathrm{c}^{\mathrm{T}}$, the background sodium content from the different components of the medium $(\sim 15 \mathrm{mM})$ was added to $\mathrm{NaCl}$ values. Substrate utilization tests were performed in duplicate under both $\mathrm{N}_{2} / \mathrm{CO}_{2}$ and $\mathrm{H}_{2} / \mathrm{CO}_{2}$ atmospheres. The latter condition was used to verify that the substrate was not inhibitory. The following substrates were tested at a final concentration of $10 \mathrm{mM}$ : sodium acetate, trimethylamine, 2-propanol, methanol, ethanol, 2-butanol, sodium propionate, sodium butyrate and sodium formate. Formate utilization tests also included treatments with or without the addition of sodium selenite $(5 \mu \mathrm{M})$ and tests at $\mathrm{pH}$ 6.4. Antibiotic susceptibility tests were performed by adding anaerobic filter-sterilized stocks of penicillin, ampicillin, vancomycin, tetracycline, bacitracin, kanamycin, spectinomycin, rifampicin and chloramphenicol (each at $100 \mu \mathrm{g}$ $\mathrm{ml}^{-1}$ final concentration). Both sodium and antibiotic sensitivity tests were done under a $\mathrm{H}_{2} / \mathrm{CO}_{2}$ atmosphere for over a month. Treatments were monitored for $\mathrm{CH}_{4}$ production with a flame ionization detector as described previously (Cadillo-Quiroz et al., 2006). Growth rates were calculated from methane production from the exponential portion of the methane accumulation curve (Ni \& Boone, 1991).

The morA gene was amplified using the ME1 and ME2 primer set as described previously (Hales et al., 1996). Phylogenetic analyses of $16 \mathrm{~S}$ rRNA gene sequences was carried out using ARB software (Ludwig et al., 2004) and the latest release (January 2007) of the 'greengenes' database (DeSantis et al., 2006). The 16S rRNA gene sequence alignment was exported from ARB using an 'Archaeal' nucleotide base frequency filter that included positions with more than $50 \%$ invariance (1140 valid columns) to avoid possible treeing artefacts. Phylogenetic trees were constructed by Bayesian analyses. The approximation of posterior probabilities was done with MRBAYES version 3.0 (Ronquist \& Huelsenbeck, 2003) using four-chain Metropolis-coupled Markov Chain Monte Carlo (MCMCMC) analysis. Trees and model parameter values were sampled from a target distribution generated when chains converged. Bayesian consensus trees were built with a burnout of 300 and posterior probabilities were calculated. Tree topology was confirmed using maximum-likelihood and neighbour-joining methods with Olsen evolutionary distance correction as implemented in the ARB software (Ludwig et al., 2004). The presented tree represents the most frequently observed topology across 
various phylogenetic analyses. For mcrA deduced amino acid sequences, sequences were aligned using CLUSTAL_X and analysed using MRBAYES under similar conditions to those described above. For this analysis, 236 aa residues were compared for the McrA tree.

The genomic DNA G $+C$ content of E1-9c ${ }^{T}$ was calculated by a thermal denaturation fluorimetric method using the Bio-Rad iCycler iQ real-time PCR system as described previously (Gonzalez \& Saiz-Jimenez, 2002). The G-nome kit (Qbiogene) was used to isolate genomic DNA from strain E1-9c $\mathrm{C}^{\mathrm{T}}$ and the following cultures: 'Candidatus Methanoregula boonei' 6A8 (G+C content $54.5 \mathrm{~mol} \%$; S. Bräuer, personal communication), Escherichia coli K-12 (50 mol\%) and Pseudomonas aeruginosa PAO1 (66 mol\%). Additionally, DNA from Micrococcus luteus ( $\mathrm{G}+\mathrm{C}$ content $72 \mathrm{~mol} \%)$ and Clostridium perfringens ( $27 \mathrm{~mol} \%)$ was obtained from commercial sources (Sigma-Aldrich). Thermal denaturation was performed with approximately $2.5 \mu \mathrm{g}$ DNA from the isolate and standards. Thermal conditions consisted of a ramp from 55 to $90{ }^{\circ} \mathrm{C}$ at $0.5{ }^{\circ} \mathrm{C} \mathrm{min}{ }^{-1}$. Fluorescent DNA melting curves were generated in triplicate. The DNA G $+\mathrm{C}$ content for strain E1-9c ${ }^{T}$ was calculated using a linear regression analysis of melting temperatures against the DNA G+C content of the standards.

Cells of E1-9c $\mathrm{c}^{\mathrm{T}}$ were regular cocci, $0.5-0.8 \mu \mathrm{m}$ in size and stained Gram-positive. The cells were mostly associated in pairs and planes of division were commonly visible (Fig. 1a). Other cocci in the Methanomicrobiales, such as those of strains of the genus Methanogenium, tend to be irregular and do not form pairs (Table 1). Methanofollis aquaemaris $\mathrm{N} 2 \mathrm{~F} 9704^{\mathrm{T}}$ forms regular cocci when in the exponential phase that change to irregular cocci in the stationary phase (Lai \& Chen, 2001). Cultures of E1-9c $c^{\mathrm{T}}$ did not show such a change in morphology. Under phase-contrast microscopy, E1-9c ${ }^{T}$ cells had a dark centre surrounded by a transparent outer layer; cells were autofluorescent when exposed to nearUV light, indicating the presence of $\mathrm{F}_{420}$, a fluorescent coenzyme often present in high concentrations in methanogens (Garcia, 1990). The cell envelope was resistant to lysis with $0.1 \%$ SDS although, at concentrations above $2 \%$, some evidence of envelope damage was observed.

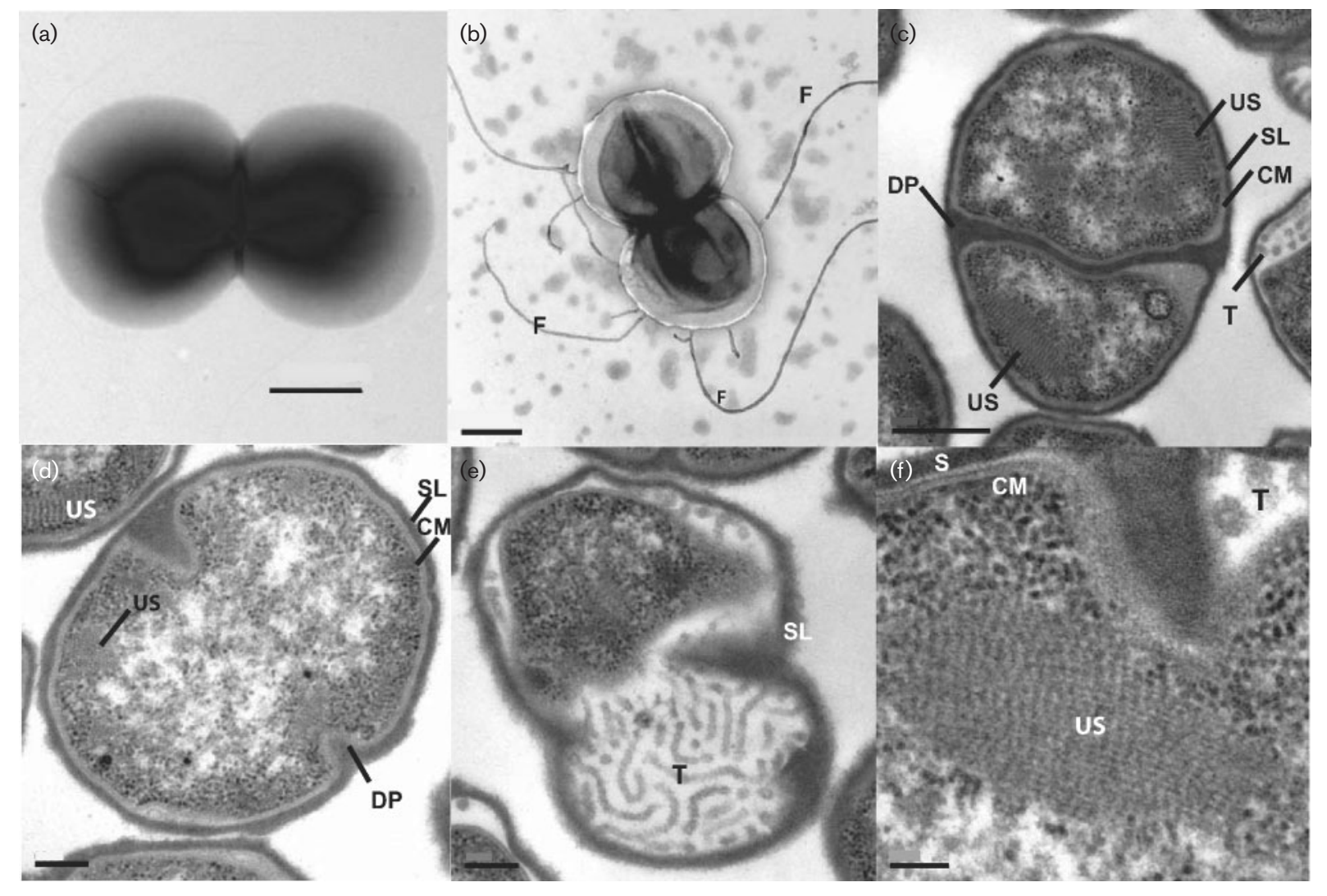

Fig. 1. TEM of cells of strain $E 1-9 c^{\top}$. (a) Negative staining showing the regular coccus morphology. Bar, $500 \mathrm{~nm}$. (b) Negative staining with low uranyl acetate addition and digital enhancement (see text) to allow contrast for the observation of multiple flagella (F). Bar, $500 \mathrm{~nm}$. (c-f) Ultrathin sectioning microscopy showing several intracellular details such as S-layer (SL), cytoplasmic membrane (CM), division plane of the cell (DP), tubular-like S-layer-connecting structures (T) and unknown intracellular structures (US). Bars, $500 \mathrm{~nm}$ (c, e), $200 \mathrm{~nm}$ (d) and $100 \mathrm{~nm}$ (f). 
Table 1. Physiological characteristics of strain $E 1-9 c^{\top}$ and other representative coccoid and closely related methanogens belonging to the order Methanomicrobiales

Strains: 1, E1-9c $\mathrm{c}^{\mathrm{T}}$ (data from this study); 2, 'Candidatus Methanoregula boonei' 6A8 (Bräuer et al., 2006a); 3, Methanolinea tarda NOBI-1 ${ }^{\mathrm{T}}$ (Imachi et al., 2008); 4, Methanospirillum hungatei JF-1 ${ }^{\mathrm{T}}$ (Balch et al., 1979; Ferry et al., 1974); 5, Methanoculleus palmolei INSLUZ ${ }^{\mathrm{T}}$ (Zellner et al., 1998); 6, Methanofollis aquaemaris $\mathrm{N} 2 \mathrm{~F} 9704^{\mathrm{T}}$ (Lai \& Chen, 2001); 7, Methanocorpusculum aggregans $\mathrm{MSt}^{\mathrm{T}}$ (Ollivier et al., 1985); 8, Methanoplanus petrolearius SEBR $4847^{\mathrm{T}}$ (Ollivier et al., 1997); 9, Methanocorpusculum parvum XII ${ }^{\mathrm{T}}$ (Zellner et al., 1987); 10, Methanocalculus halotolerans SEBR $4845^{\mathrm{T}}$ (Ollivier et al., 1998). All strains used $\mathrm{H}_{2} / \mathrm{CO}_{2}$ as methanogenic substrate. ND, No data available.

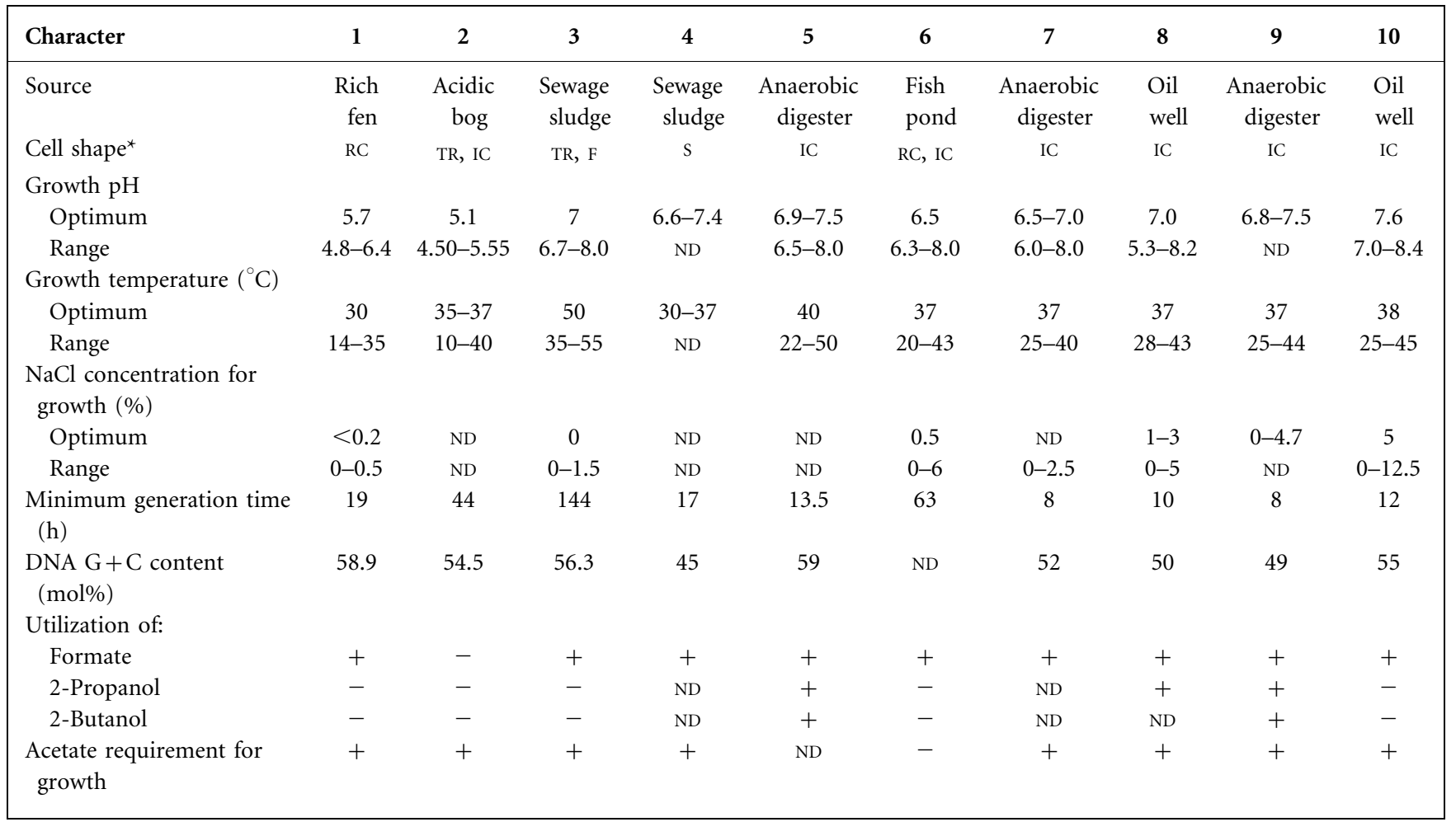

${ }^{\star} \mathrm{F}$, Filaments; IC, irregular cocci; RC, regular cocci; s, spirilla; TR, thin rods.

TEM of negatively stained cells (Fig. 1b) showed that cells of E1-9c $c^{\mathrm{T}}$ possessed multiple flagella. Flagella were around $14 \mathrm{~nm}$ thick and could reach lengths of 8-12 $\mu \mathrm{m}$. Flagella were readily lost under stress conditions such as high-speed centrifugation and oxic environments, perhaps explaining the absence of motility in light microscopy observations of wet mounts. An electron-dense cell wall about 30-70 nm thick was observed in thin sections (Fig. 1c-f), and negative staining of the cell surface did not show a pattern that was characteristic of outer S-layers (not shown). Most strains of the Methanomicrobiales are sensitive to lysis with dilute detergents because they possess a single S-layer cell wall, and strains with this type of cell wall commonly stain Gram-negative (Boone et al., 1993). Electron microscopy, resistance to SDS lysis and Gram-positive staining observations suggest that the cell wall of E1-9c $c^{\mathrm{T}}$ is different from a single $\mathrm{S}$-layer and that this thick layer may play a role in adaptation to low-ionic-strength environments, analogous to the methanochondroitin layer in Methanosarcina species (Sprott \& Beveridge, 1994). In thin sections, the cytoplasm of some cells apparently shrank away from the outer layer as a result of the osmotic strength of the $2 \%$ glutaraldehyde fixative, and tubular structures were visible in the intervening space ( $\mathrm{T}$ in Fig. $1 c, e, f)$. It has been suggested that these tubular structures connect the S-layer to the cytoplasmic membrane (Sprott \& Beveridge, 1994) and they are identical in appearance to those observed in Methanosarcina mazei (Robinson, 1986). Additionally, in many cells, an unknown structure was observed in the cytoplasm (US in Fig. 1c, d, f) resembling arrays of protein complexes, $\sim 10 \mathrm{~nm}$ in diameter, that were less electron-dense than ribosomes. These structures do not resemble the 'methanochondrion' internal membrane systems, now believed to be preparation artefacts (Sprott \& Beveridge, 1994). The potential protein complexes are similar in size to purified methylcoenzyme $M$ methylreductase complexes $(\sim 10 \mathrm{~nm})$ and smaller than $\mathrm{F}_{420^{-}}$ reducing hydrogenase complexes $(\sim 15 \mathrm{~nm})$ (Wackett et al., 1987).

Our previous report (Cadillo-Quiroz et al., 2008) showed that $\mathrm{E} 1-9 \mathrm{c}^{\mathrm{T}}$ is a mesophile with optimal growth at 28$30{ }^{\circ} \mathrm{C}$ and that it is mildly acidiphilic, with an optimum $\mathrm{pH}$ of about 5.5 and a narrow $\mathrm{pH}$ range of 4.8-6.4. Only a few 
(a)

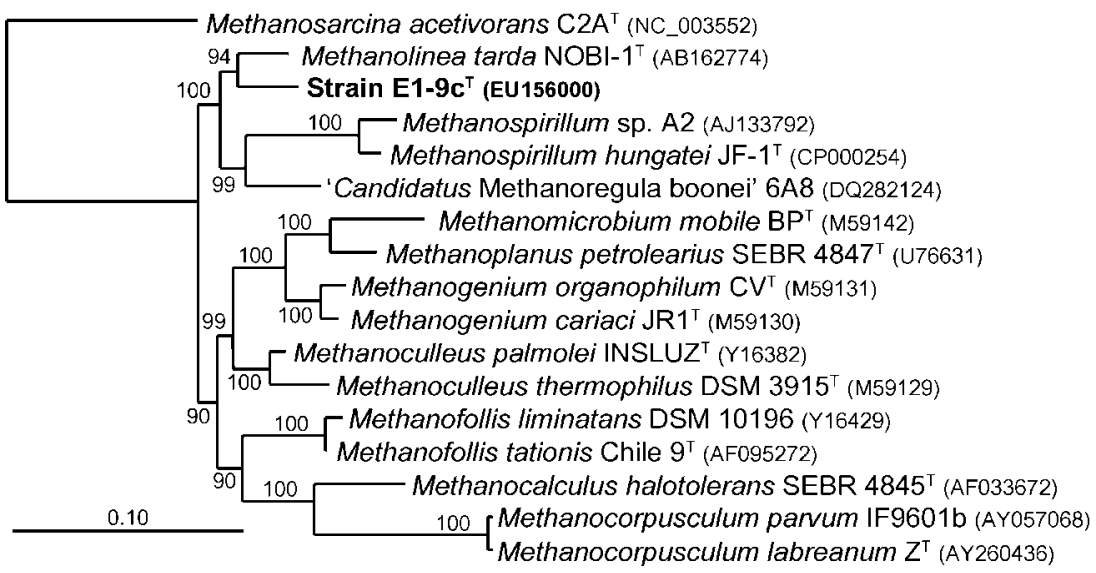

(b)
Fig. 2. Phylogenetic analysis of strain $E 1-9 c^{\top}$ and members of the order Methanomicrobiales based on 16S rRNA gene sequences (a) and deduced amino acid sequences from the $m c r A$ gene (b). Accession numbers are shown in parentheses. Bar, 0.1 changes per sequence position. other methanogens have been described with a $\mathrm{pH}$ optimum < 5.5. 'Candidatus Methanoregula boonei' 6A8, in the order Methanomicrobiales, isolated from an acidic ( $\mathrm{pH} 4.5$ ) bog peatland, is the most acidiphilic methanogen described to date, with optimal pH around 5.1 (Bräuer et al., 2006a). Methanobacterium espanolae, isolated from pulp mill waste sludge, represents the next most acidiphilic reported methanogen, with optimum $\mathrm{pH}$ around 5.6 (Patel et al., 1990). Strain E1-9c $\mathrm{c}^{\mathrm{T}}$ has a lower optimum $\mathrm{pH}$ than that of the fen from which it was isolated $(\mathrm{pH} \mathrm{6.5)}$.

The optimum total $\mathrm{Na}^{+}$concentration for strain E1-9c was between 15 (background $\mathrm{Na}^{+}$concentration in medium) and $35 \mathrm{mM}$; concentrations above $100 \mathrm{mM}$ strongly inhibited growth (Supplementary Fig. S1, available in IJSEM Online). Strain E1-9c $\mathrm{c}^{\mathrm{T}}$ tolerated $<0.5 \% \mathrm{NaCl}$, a value lower than those found for many strains isolated from other non-marine sources (Table 1). The inhibitory concentration of total $\mathrm{Na}^{+}$for $\mathrm{E} 1-9 \mathrm{c}^{\mathrm{T}}$ was nearly twice that of 'Candidatus Methanoregula boonei' (S. Bräuer, personal communication). The difference in $\mathrm{Na}^{+}$tolerance between E1-9c $\mathrm{c}^{\mathrm{T}}$ and 'Candidatus Methanoregula boonei' could hypothetically reflect an adaptation to the difference in total $\mathrm{Na}^{+}$concentration observed in the pore water of Michigan Hollow $\left(\sim 30 \mu \mathrm{M} \mathrm{Na}{ }^{+}\right)$versus McLean Bog $\left(\sim 2 \mu \mathrm{M} \mathrm{Na}^{+}\right)$(Dettling et al., 2007), the respective sources of each bacterium. E1-9c $c^{\mathrm{T}}$ was also highly sensitive to $\mathrm{Na}_{2} \mathrm{~S}$ concentrations. E1-9c $c^{\mathrm{T}}$ required $\mathrm{Na}_{2} \mathrm{~S}$ as a sulfur source (Rajagopal \& Daniels, 1986), but concentrations above $0.1 \mathrm{mM}$ were inhibitory (Cadillo-Quiroz et al., 2008). $\mathrm{Na}_{2} \mathrm{~S}$ is commonly used as a reducing agent at concentrations between 1 and $2 \mathrm{mM}$ (Sowers \& Noll, 1995).

In terms of methanogenic substrates, E1-9c $\mathrm{c}^{\mathrm{T}}$ cultures used $\mathrm{H}_{2} / \mathrm{CO}_{2}$ and formate, but not acetate, trimethylamine, 2propanol, methanol, ethanol, 2-butanol, propionate or sodium butyrate (all at $10 \mathrm{mM}$ final concentration) as substrates for methanogenesis. With the exception of formate, none of these substrates were inhibitory during growth with $\mathrm{H}_{2} / \mathrm{CO}_{2}$. Formate additions (10 or $20 \mathrm{mM}$ ) caused a 3- to 4-week lag in growth in tubes also supplemented with $\mathrm{H}_{2} / \mathrm{CO}_{2}$ (Supplementary Fig. S2). Formate is commonly used by members of the order Methanomicrobiales (Boone et al., 2001); however, formate can be toxic at concentrations $<100 \mathrm{mM}$ at low $\mathrm{pH}(<6)$ and, in some strains, formate dehydrogenase activity is dependent on the presence of selenium (Belay et al., 1986; Jarrell \& Kalmokoff, 1988; Sparling \& Daniels, 1990). Therefore, additional experiments were performed to address the potential formate toxicity at low $\mathrm{pH}$ and the selenium requirement. At pH 5.7, strain E1-9 $\mathrm{c}^{\mathrm{T}}$ was able to use formate at low concentrations, as shown by the stoichiometric increase of methane following multiple additions of 10-20 mM formate (Supplementary Fig. S2). 
Formate additions above $50 \mathrm{mM}$ inhibited growth of strain E1-9c $\mathrm{c}^{\mathrm{T}}$. Higher $\mathrm{pH}$ (6.4) or the addition of selenite (1 and $10 \mu \mathrm{M})$ did not improve the use of formate (Supplementary Fig. S2). The addition of $1 \mu \mathrm{M}$ selenite accentuated the inhibitory effects of formate in tubes with $\mathrm{H}_{2} / \mathrm{CO}_{2}$ (Supplementary Fig. S2).

In addition to $\mathrm{H}_{2} / \mathrm{CO}_{2}$ as methanogenic substrate and mineral nutrients, E1-9 $\mathrm{c}^{\mathrm{T}}$ required vitamins, coenzyme $\mathrm{M}$ and acetate for growth. The use of acetate as a carbon source has been observed in many $\mathrm{H}_{2} / \mathrm{CO}_{2}$-utilizing methanogens (Balch et al., 1979; Belay et al., 1986; Bott et al., 1985; Jarrell \& Kalmokoff, 1988). For instance, Methanospirillum hungatei requires acetate at levels around $18 \mathrm{mM}$ (Sprott \& Jarrell, 1981) and acetate can contribute up to $65 \%$ of total cellular carbon in Methanothermobacter thermoautotrophicus (Fuchs et al., 1978). It was found that acetate concentrations around $4 \mathrm{mM}$ were optimal for growth of E1-9c ${ }^{T}$ under $\mathrm{H}_{2} / \mathrm{CO}_{2}$ and that concentrations above $20 \mathrm{mM}$ did not further stimulate growth (data not presented). E1-9c $\mathrm{c}^{\mathrm{T}}$ doubling times were $\sim 30 \mathrm{~h}$ with $0.4 \mathrm{mM}$ acetate (concentration used in the isolation of the strain) and $\sim 19 \mathrm{~h}$ with $4 \mathrm{mM}$ acetate under standard growth conditions of $\mathrm{pH} 5.7$ and $30{ }^{\circ} \mathrm{C}$.

Strain $\mathrm{E} 1-9 \mathrm{c}^{\mathrm{T}}$ was resistant to penicillin, ampicillin, vancomycin, tetracycline, bacitracin, kanamycin, spectinomycin and rifampicin (all at $100 \mu \mathrm{g} \mathrm{ml}^{-1}$ ), but chloramphenicol inhibited growth.

The full 16S rRNA gene and intergenic transcribed sequence were determined for strain E1-9 $\mathrm{c}^{\mathrm{T}}$ and phylogenetic analysis showed that this strain was closely associated with environmental sequence subcluster ' $c$ ' of the E1 group (Cadillo-Quiroz et al., 2008). The E1 group is an independent lineage within the order Methanomicrobiales (Cadillo-Quiroz et al., 2006, 2008). Therefore, 16S rRNA gene and mcrA-based phylogenetic trees were constructed (Fig. 2) with predicted sequences of representative strains of the reported genera in this order. Sequences from the recently described methanogens 'Candidatus Methanoregula boonei' 6A8 (Bräuer et al., 2006a) and Methanolinea tarda NOBI- $1^{\mathrm{T}}$ (Imachi et al., 2008; Sakai et al., 2007) were also included. Phylogenetic analysis based on 16S rRNA gene sequences showed that E1-9 $\mathrm{c}^{\mathrm{T}}$ was divergent from all other described genera within the Methanomicrobiales and possessed no more than $85-92 \%$ sequence identity to strains of any other genus. The phylogenetic branching order in Fig. 2(a) indicates that Methanospirillum, and hence the family Methanospirillaceae, is the most closely related group ( $90 \%$ identity). However, in terms of sequence identity, the closest relatives of strain E1-9c ${ }^{\mathrm{T}}$ were Methanolinea tarda NOBI- $1^{\mathrm{T}}$ (94\% identity) followed by 'Candidatus Methanoregula boonei' 6A8 and Methanoculleus palmolei INSLUZ $^{\mathrm{T}}$ (both with $92 \%$ identity). Phylogenetic analysis of amino acid sequences predicted from the $m c r A$ gene supported strain E1-9 $\mathrm{c}^{\mathrm{T}}$ as an independent branch in the Methanomicrobiales although, when compared with the 16S
rRNA gene sequence analysis, some differences were observed in the branching order and order of sequence similarity with its closest relatives (Fig. 2). McrA sequence analysis showed the following order in terms of the predicted amino acid sequence identities (\%) to E1-9c $\mathrm{c}^{\mathrm{T}}$ : Methanoculleus palmolei INSLUZ $^{\mathrm{T}}(83 \%)$ as the closest, followed by Methanospirillum hungatei JF- $1^{\mathrm{T}}(82 \%)$ and then 'Candidatus Methanoregula boonei' 6A8 and Methanolinea tarda NOBI- $1^{\mathrm{T}}$ (both $81 \%$ ). In contrast to the $16 \mathrm{~S}$ rRNA gene analysis, NOBI- $1^{\mathrm{T}}$ was more distantly related to $E 1-9 c^{T}$; however, the branching positions of strains NOBI- $1^{\mathrm{T}}, \mathrm{E} 1-9 \mathrm{c}^{\mathrm{T}}$ and $6 \mathrm{~A} 8$ were highly variable in the multiple analyses of predicted amino acid sequences of the $m c r A$ gene, indicating that these sequences did not provide a robust phylogeny for these organisms.

A comparison of phenotypic (Table 1) and phylogenetic (Fig. 2) characteristics of strain E1-9 $\mathrm{c}^{\mathrm{T}}$ indicates its uniqueness among members of the order Methanomicrobiales, allowing us to propose it as the type strain of a novel species in a new genus, Methanosphaerula palustris gen. nov., sp. nov. It is proposed that this genus be a genus incertae sedis, temporarily not affiliated to any of the known families in this order. Phylogenetic analysis based on 16S rRNA gene sequences of members of the order Methanomicrobiales showed that the phylogenetic divergence of E1-9 $\mathrm{c}^{\mathrm{T}}$ from members of the other families (85$92 \%$ identity) was close to the divergence levels observed among the families themselves (82-89\%), which suggests that E1-9c could represent a new family. It is expected that the more detailed genomic analysis of this strain presently under way and the isolation and description of additional related strains will allow a better evaluation of the taxonomy of these novel organisms within the Methanomicrobiales.

\section{Description of Methanosphaerula gen. nov.}

Methanosphaerula [Me.tha.no.sphae.ru'la. N.Gr. n. methane (from N. Gr. n. meth $(y l)$ and chemical suffix -ane) methane; L. fem. n. sphaerula a small sphere; N.L. fem. n. Methanosphaerula small spherical methane-producer].

Cells are cocci and are often found in pairs. Methanogenic and strictly anaerobic members of the domain Archaea. Mesophilic and mildly acidiphilic; produce methane from $\mathrm{H}_{2} / \mathrm{CO}_{2}$ and formate. The type species is Methanosphaerula palustris.

\section{Description of Methanosphaerula palustris sp. nov.}

Methanosphaerula palustris (pa.lus'tris. L. fem. adj. palustris marshy, swampy or muddy, living in marshes).

Cells stain Gram-positive and do not lyse with $0.1 \%$ SDS. Cells are $0.5-0.8 \mu \mathrm{m}$ in diameter and autofluorescent when exposed to near-UV light. The optimum $\mathrm{pH}$ is about 5.5; growth occurs at $\mathrm{pH}$ 4.8-6.4. The temperature optimum is about $30{ }^{\circ} \mathrm{C}$ with growth occurring at $14-35^{\circ} \mathrm{C}$. Optimal 
growth is observed in $15-35 \mathrm{mM}$ total $\mathrm{Na}^{+}$, but no growth is observed in the presence of $\geqslant 100 \mathrm{mM}$ total $\mathrm{Na}^{+}$or $\geqslant 0.5 \% \mathrm{NaCl}$. Doubling time is about $19 \mathrm{~h}$ under optimal conditions. Methane is produced from $\mathrm{H}_{2} / \mathrm{CO}_{2}$ or formate, but not from ethanol, methanol, 2-propanol, 2-butanol, acetate, propionate or butyrate. Formate concentrations $>50 \mathrm{mM}$ are inhibitory at $\mathrm{pH}$ 5.5. Vitamins, coenzyme M, acetate $(4 \mathrm{mM})$ and low concentrations of $\mathrm{Na}_{2} \mathrm{~S}$ $(<0.08 \mathrm{mM})$ are required for growth.

The type strain is $\mathrm{E} 1-9 \mathrm{c}^{\mathrm{T}}$ (=ATCC BAA- $1565^{\mathrm{T}}=\mathrm{DSM}$ $\left.19958^{\mathrm{T}}\right)$, isolated from minerotrophic fen peatland. The DNA G + C content of the type strain is $58.9 \pm 2 \mathrm{~mol} \%$.

\section{Acknowledgements}

We are thankful to the Cornell Integrated Microscopy Center (CIMC) personnel for their help with electron microscopy, S. Bräuer and J. Ben-Hain for their help in culturing efforts, J. P. Euzéby for his assistance on name derivation and L. Salzberg for useful comments on the manuscript. This work was supported by the NSF Microbial Observatories program grant (0132049).

\section{References}

Balch, W. E., Fox, G. E., Magrum, L. J., Woese, C. R. \& Wolfe, R. S. (1979). Methanogens: reevaluation of a unique biological group. Microbiol Rev 43, 260-296.

Basiliko, N., Yavitt, J. B., Dees, P. M. \& Merkel, S. (2003). Methane biogeochemistry and methanogen communities in two northern peatland ecosystems, New York State. Geomicrobiol J 20, 563-577.

Belay, N., Sparling, R. \& Daniels, L. (1986). Relationship of formate to growth and methanogenesis by Methanococcus thermolithotrophicus. Appl Environ Microbiol 52, 1080-1085.

Boone, D. R. \& Whitman, W. B. (1988). Proposal of minimal standards for describing new taxa of methanogenic bacteria. Int J Syst Bacteriol 38, 212-219.

Boone, D. R., Whitman, W. B. \& Rouvière, P. (1993). Diversity and taxonomy of methanogens. In Methanogenesis: Ecology, Physiology, Biochemistry and Genetics, pp. 35-80. Edited by J. G. Ferry. New York: Chapman \& Hall.

Boone, D. R., Whitman, W. B. \& Koga, Y. (2001). Order II. Methanomicrobiales Balch and Wolfe 1981, 216 ${ }^{\mathrm{VP}}$. In Bergey's Manual of Systematic Bacteriology, 2nd edn, vol. 1, pp. 246-247. Edited by G. M. Garrity, D. R. Boone \& R. W. Castenholz. New York: Springer.

Bott, M. H., Eikmanns, B. \& Thauer, R. K. (1985). Defective formation and/or utilization of carbon monoxide in $\mathrm{H}_{2} / \mathrm{CO}_{2}$ fermenting methanogens dependent on acetate as carbon source. Arch Microbiol 143, 266-269.

Bräuer, S. L., Cadillo-Quiroz, H., Yashiro, E., Yavitt, J. B. \& Zinder, S. H. (2006a). Isolation of a novel acidiphilic methanogen from an acidic peat bog. Nature 442, 192-194.

Bräuer, S. L., Yashiro, E., Ueno, N. G., Yavitt, J. B. \& Zinder, S. H. (2006b). Characterization of acid-tolerant $\mathrm{H}_{2} / \mathrm{CO}_{2}$-utilizing methanogenic enrichment cultures from an acidic peat bog in New York State. FEMS Microbiol Ecol 57, 206-216.

Cadillo-Quiroz, H., Bräuer, S., Yashiro, E., Sun, C., Yavitt, J. \& Zinder, S. (2006). Vertical profiles of methanogenesis and methanogens in two contrasting acidic peatlands in central New York State, USA. Environ Microbiol 8, 1428-1440.
Cadillo-Quiroz, H., Yashiro, E., Yavitt, J. B. \& Zinder, S. H. (2008). Characterization of the archaeal community in a minerotrophic fen and terminal restriction fragment length polymorphism-directed isolation of a novel hydrogenotrophic methanogen. Appl Environ Microbiol 74, 2059-2068.

Cicerone, R. J. \& Oremland, R. S. (1988). Biogeochemical aspects of atmospheric methane. Global Biogeochem Cycles 2, 299-327.

DeSantis, T. Z., Hugenholtz, P., Larsen, N., Rojas, M., Brodie, E. L., Keller, K., Huber, T., Dalevi, D., Hu, P. \& Andersen, G. L. (2006). Greengenes, a chimera-checked 16S rRNA gene database and workbench compatible with ARB. Appl Environ Microbiol 72, 50695072.

Dettling, M. D., Yavitt, J. B., Cadillo-Quiroz, H., Sun, C. \& Zinder, S. H. (2007). Soil-methanogen interactions in two peatlands (bog, fen) in central New York State. Geomicrobiol J 24, 247-259.

Dubach, A. C. \& Bachofen, R. (1985). Methanogens: a short taxonomic overview. Experientia 41, 441-446.

Ferry, J. G., Smith, P. H. \& Wolfe, R. S. (1974). Methanospirillum, a new genus of methanogenic bacteria, and characterization of Methanospirillum hungatii sp. nov. Int J Syst Bacteriol 24, 465-469.

Firtel, M., Southam, G., Mok, T., Harris, R. \& Beveridge, T. J. (1995). Electron microscopy techniques for the Archaea. In Archaea: $a$ Laboratory Manual, vol. 2, Methanogens, pp. 123-140. Edited by K. R. Sowers \& H. J. Schreier. Cold Spring Harbor, NY: Cold Spring Harbor Laboratory.

Fuchs, G., Stupperich, E. \& Thauer, R. K. (1978). Acetate assimilation and the synthesis of alanine, aspartate and glutamate in Methanobacterium thermoautotrophicum. Arch Microbiol 117, 61-66.

Galand, P. E., Fritze, H. \& Yrjälä, K. (2003). Microsite-dependent changes in methanogenic populations in a boreal oligotrophic fen. Environ Microbiol 5, 1133-1143.

Garcia, J. L. (1990). Taxonomy and ecology of methanogens. FEMS Microbiol Rev 87, 297-308.

Garcia, J. L., Patel, B. K. C. \& Ollivier, B. (2000). Taxonomic, phylogenetic, and ecological diversity of methanogenic Archaea. Anaerobe 6, 205-226.

Gonzalez, J. M. \& Saiz-Jimenez, C. (2002). A fluorimetric method for the estimation of $\mathrm{G}+\mathrm{C}$ mol $\%$ content in microorganisms by thermal denaturation temperature. Environ Microbiol 4, 770-773.

Gore, A. J. P. (1983). Ecosystems of the World 4B. Mires: Swamp, Bog, Fen and Moor. Regional Studies. Amsterdam: Elsevier Scientific.

Gorham, E. (1991). Northern peatlands: role in the carbon cycle and probable responses to climatic warming. Ecol Appl 1, 182-195.

Hales, B. A., Edwards, C., Ritchie, D. A., Hall, G., Pickup, R. W. \& Saunders, J. R. (1996). Isolation and identification of methanogenspecific DNA from blanket bog peat by PCR amplification and sequence analysis. Appl Environ Microbiol 62, 668-675.

Imachi, H., Sakai, S., Sekiguchi, Y., Hanada, S., Kamagata, Y., Ohashi, A. \& Harada, H. (2008). Methanolinea tarda gen. nov., sp. nov., a methane-producing archaeon isolated from a methanogenic digester sludge. Int J Syst Evol Microbiol 58, 294-301.

Jarrell, K. F. \& Kalmokoff, M. L. (1988). Nutritional requirements of the methanogenic archaebacteria. Can J Microbiol 34, 557-576.

Kotsyurbenko, O. R., Chin, K. J., Glagolev, M. V., Stubner, S., Simankova, M. V., Nozhevnikova, A. N. \& Conrad, R. (2004). Acetoclastic and hydrogenotrophic methane production and methanogenic populations in an acidic West-Siberian peat bog. Environ Microbiol 6, 1159-1173.

Lai, M. C. \& Chen, S. C. (2001). Methanofollis aquaemaris sp. nov., a methanogen isolated from an aquaculture fish pond. Int J Syst Evol Microbiol 51, 1873-1880. 
Lai, M. C., Chen, S. C., Shu, C. M., Chiou, M. S., Wang, C. C., Chuang, M. J., Hong, T. Y., Liu, C. C., Lai, L. J. \& Hua, J. J. (2002). Methanocalculus taiwanensis sp. nov., isolated from an estuarine environment. Int J Syst Evol Microbiol 52, 1799-1806.

Lai, M. C., Lin, C. C., Yu, P. H., Huang, Y. F. \& Chen, S. C. (2004). Methanocalculus chunghsingensis sp. nov., isolated from an estuary and a marine fishpond in Taiwan. Int J Syst Evol Microbiol 54, 183-189.

Ludwig, W., Strunk, O., Westram, R., Richter, L., Meier, H., Yadhukumar, Buchner, A., Lai, T., Steppi, S. \& other authors (2004). ARB: a software environment for sequence data. Nucleic Acids Res 32, 1363-1371.

Mori, K., Yamamoto, H., Kamagata, Y., Hatsu, M. \& Takamizawa, K. (2000). Methanocalculus pumilus sp. nov., a heavy-metal-tolerant methanogen isolated from a waste-disposal site. Int J Syst Evol Microbiol 50, 1723-1729.

Ni, S. S. \& Boone, D. R. (1991). Isolation and characterization of a dimethyl sulfide-degrading methanogen, Methanolobus siciliae HI350, from an oil well, characterization of $M$. siciliae T4/MT, and emendation of $M$. siciliae. Int J Syst Bacteriol 41, 410-416.

Ollivier, B. M., Mah, R. A., Garcia, J. L. \& Robinson, R. (1985). Isolation and characterization of Methanogenium aggregans sp. nov. Int J Syst Bacteriol 35, 127-130.

Ollivier, B., Cayol, J. L., Patel, B. K. C., Magot, M., Fardeau, M. L. \& Garcia, J. L. (1997). Methanoplanus petrolearius sp. nov., a novel methanogenic bacterium from an oil-producing well. FEMS Microbiol Lett 147, 51-56.

Ollivier, B., Fardeau, M. L., Cayol, J. L., Magot, M., Patel, B. K., Prensier, G. \& Garcia, J. L. (1998). Methanocalculus halotolerans gen. nov., sp. nov., isolated from an oil-producing well. Int J Syst Bacteriol 48, 821-828.

Patel, G. B., Sprott, G. D. \& Fein, J. E. (1990). Isolation and characterization of Methanobacterium espanolae sp. nov., a mesophilic, moderately acidiphilic methanogen. Int J Syst Bacteriol 40, 12-18.

Rajagopal, B. S. \& Daniels, L. (1986). Investigation of mercaptans, organic sulfides, and inorganic sulfur compounds as sulfur sources for the growth of methanogenic bacteria. Curr Microbiol 14, 137-144.
Robinson, R. W. (1986). Life cycles in the methanogenic archaebacterium Methanosarcina mazei. Appl Environ Microbiol 52, 17-27.

Ronquist, F. \& Huelsenbeck, J. P. (2003). MrBayes 3: Bayesian phylogenetic inference under mixed models. Bioinformatics 19, 15721574.

Sakai, S., Imachi, H., Sekiguchi, Y., Ohashi, A., Harada, H. \& Kamagata, Y. (2007). Isolation of key methanogens for global methane emission from rice paddy fields: a novel isolate affiliated with the clone cluster rice cluster I. Appl Environ Microbiol 73, 43264331.

Sowers, K. R. \& Noll, K. M. (1995). Techniques for anaerobic growth. In Archaea: a Laboratory Manual, vol. 2, Methanogens, pp. 15-48. Edited by K. R. Sowers \& H. J. Schreier. Cold Spring Harbor, NY: Cold Spring Harbor Laboratory.

Sparling, R. \& Daniels, L. (1990). Regulation of formate dehydrogenase activity in Methanococcus thermolithotrophicus. J Bacteriol 172, 1464-1469.

Sprott, G. D. \& Beveridge, T. J. (1994). Microscopy. In Methanogenesis: Ecology, Physiology, Biochemistry and Genetics, pp. 81-172. Edited by F. G. Ferry. New York: Chapman \& Hall.

Sprott, G. D. \& Jarrell, K. F. (1981). $\mathrm{K}^{+}, \mathrm{Na}^{+}$, and $\mathrm{Mg}^{2+}$ content and permeability of Methanospirillum hungatei and Methanobacterium thermoautotrophicum. Can J Microbiol 27, 444-451.

Wackett, L. P., Hartwieg, E. A., King, J. A., Orme-Johnson, W. H. \& Walsh, C. T. (1987). Electron microscopy of nickel-containing methanogenic enzymes: methyl reductase and F420-reducing hydrogenase. J Bacteriol 169, 718-727.

Zellner, G., Alten, C., Stackebrandt, E., Conway de Macario, E. \& Winter, J. (1987). Isolation and characterization of Methanocorpusculum parvum, gen. nov., spec. nov., a new tungsten requiring, coccoid methanogen. Arch Microbiol 147, 13-20.

Zellner, G., Messner, P., Winter, J. \& Stackebrandt, E. (1998). Methanoculleus palmolei sp. nov., an irregularly coccoid methanogen from an anaerobic digester treating wastewater of a palm oil plant in North-Sumatra, Indonesia. Int J Syst Bacteriol 48, 1111-1117. 